\title{
INFECTIOUS HYPODERMAL AND HEMATOPOIETIC NECROSIS VIRUS (IHHNV) IN WILD PARENT STOCKS OF BLUE SHRIMP, Penaeus stylirostris (STIMPSON), IN GUAYMAS BAY, SONORA, MEXICO
}

\section{NECROSIS INFECCIOSA VIRAL DEL TEJIDO HIPODÉRMICO Y HEMATOPOIÉTICO (IHHNV) EN REPRODUCTORES SILVESTRES DE CAMARÓN AZUL, Penaeus stylirostris (STIMPSON), EN LA BAHÍA DE GUAYMAS, SONORA, MÉXICO}

\author{
Marco Linné Unzueta-Bustamante ${ }^{1 *}$ \\ K.H. Holtschmit ${ }^{2}$ \\ J.A. Olivas-Valdez \\ L.R. Martínez-Córdova ${ }^{3}$ \\ M.A. Porchas-Corncjo' \\ M.L. Lizárraga-Partida ${ }^{4}$ \\ ${ }^{1}$ CIBNOR, S.C., Unidad Guaymas \\ Km. 2.35 Camino al Tular, Estero de Bacochibampo \\ Apartado postal 349 \\ Guaymas, Sonora, México \\ *E-mail:mlinne@cibnor.mx \\ 2 ITESM, Unidad Guaymas \\ Bahia de Bacochibampo s/n \\ Guaymas, Sonora, Mexico \\ ${ }^{3}$ DICTUS \\ Universidad de Sonora \\ Apartado postal 1819 \\ Ilcrmosillo, Sonora, México \\ ${ }^{4}$ CICESE \\ Apartado postal 2732 \\ Ensenada, Baja California, México
}

Recibido en enero de 1998; aceptado en julio de 1998

\section{ABSTRACT}

A study was conducted to evaluate the presence of the infectious hypodermal and hematopoietic necrosis virus (IHHNV) in wild parent stocks of blue shrimp, Penaeus stylirostris, in Guaymas Bay, Sonora, Mexico. The procedure used to detect the virus was the ShrimpProbe Test Kit Dot Blot, DiagXotic, Inc. Results showed that the virus was present in $49 \%$ of the 100 shrimp studied. Males were more infected $(54 \%)$ than females $(44 \%)$. Infection in both sexes was more frequent in size classes 
$36-40$ and $31-35 \mathrm{~mm}$. For males, the highest percentages of infections were found in size classes 36-40, $31-35$ and $46-50 \mathrm{~mm}$; for females, in size classes $36-40,31-35$ and $41-45 \mathrm{~mm}$ (only size classes from $31-35$ to $51-55 \mathrm{~mm}$ were considered).

Key words: IHHNV, Penaeus stylirostris, infected wild stocks, Mexico.

\section{RESUMEN}

Se evaluó la presencia de la necrosis infecciosa viral del tejido hipodérmico y hematopoiético (IHHNV) en reproductores silvestres de camarón azul, Penaeus stylirostris, capturados en la Bahía de Guaymas, Sonora, México. Para la detección de IHHNV, se utilizó el kit comercial ShrimProbe Test Kit Dot Blot, DiagXotics, Inc. Los resultados muestran que el virus se encuentra presente en el $49 \%$ de los 100 organismos analizados. Se observa una mayor prevalencia en los machos (54\%) que en las hembras $(44 \%)$. En ambos sexos la infección fue más frecuente en las clases de talla de $36-40$ y $31-35 \mathrm{~mm}$. Para machos, el más alto porcentaje de infección se presentó en las clases de talla de 36-40,31--35 y 46-50 mm; para hembras, en las clases de talla de 36-40, 31-35 y $41-45 \mathrm{~mm}$ (solamente se consideraron las clases de talla de $31-35$ a $51-55 \mathrm{~mm}$ ).

Palabras clave: IHHNV, Penaeus stylirostris, reproductores silvestres infectados, México.

\section{INTRODUCTION}

Shrimp mariculture is an important industry world-wide. At present, farmed shrimp production throughout the world exceeds $700,000 \mathrm{mt}$ (Rosenberry, 1995). This activity, however, has to face some challenges for its future development. The most important of these challenges are: (a) the design of appropriate and inexpensive diets to reduce production costs; (b) the supply of high quality seed stock (postlarvae); (c) the efficient management of the culture system; and (d) the detection, prevention and control of epizootics, which can significantly affect this industry. Some pathogens and the diseases they produce have been labeled (justifiably or not) as causes of the failure of many shrimp farm enterprises; however, the rapid and accurate detection of the etiological agents will prevent the dissemination of diseases in mariculture (Conroy and Conroy, 1990). It is very important to avoid the use of infected seed stocks or parent stocks because they will surely transmit the pathogens to the progeny.

At present, there are around a dozen viral diseases reported for both wild and farmed penaeid shrimp. Four of them (BP, IHHN, HPV

\section{INTRODUCCIÓN}

El cultivo de camarón es una industria importante a nivel mundial. En la actualidad, la producción de camarón cultivado en el mundo es superior a las 700,000 t (Rosenberry, 1995). Esta actividad, sin embargo, tiene que enfrentar algunos desafios para su futuro desarrollo. Los más importantes de estos desafios son: (a) el diseño de dietas adecuadas y baratas que permitan reducir los costos de producción; (b) el abastecimiento de postlarvas de alta calidad producidas en el laboratorio, para la siembra de estanques; (c) el manejo eficiente de los sistemas de cultivo; y (d) la detección, prevención y el control de epizootias que pueden afectar significativamente esta industria. Algunos patógenos $\mathrm{y} / \mathrm{o}$ enfermedades han sido culpadas (en forma justificada o no) del fracaso de muchas granjas de camarón; sin embargo, la detección rápida y precisa de los agentes etiológicos nos puede permitir la prevención de la diseminación de enfermedades en los cultivos (Conroy y Conroy, 1990). Es muy importante evitar el uso de reproductores infectados para el abastecimiento de postlarvas, ya que ellos son transmisores potenciales de patógenos a la progenie. 
and TSV) have had significant impacts on American shrimp hatcheries and farms (Brock et al. . 1983). Other viruses, such as REO III and LOVV. that affect American shrimp are being characterized.

The presence of IIHHV has been reported since 1989 in wild and farmed shrimp in Mexico, Central and South America. This indicates that it is widely distributed in wild populations of the American Pacific (Lotz et al. 1989; Lightner and Redman, 1991). Before 1987, farmed and wild shrimp from the Gulf of California were reported to be free of IHHNV (Lightner et al, 1992). Later, there were reports of infections in farms and hatcheries. Around 1989, some studies suggested that the virus may be present in wild populations (Lotz et al., 1991). This virus has been reported for the most commonly farmed American species, blue and white shrimp (Penceus stylirostris and $P$. vannamei). and for yellowleg shrimp ( $P$. californiensis) from the Gulf of California (Pantoja-Morales and Lightner, 1991). At present. yeltowleg shrimp are not commercially farmed, but the potential for doing so exists in Mexico (Magallon-Barajas et al.. 1994).

The IHHIN virus is a member of the family Parvoviridae (Bonami et al., 1990). Its diameter ranges from 20 to $22 \mathrm{~nm}$. Its symmetry is icosahedronic. It is made up of a simple DNA chain, with a capsid of four polypeptides with molecular weights of 74. 47, 39 and $37.5 \mathrm{Kd}$ (Poulos and lightner, 1992)

The blue shrimp, P. stylirostris, is extremely susceptible to IHHNV infection, and some epizootics have occurred in semi-intensive and intensive farms (Lightner and Redman, 1992). In other penaeid shrimp, such as $P$. semisulcatus, $P$. chinensis and $P$. californiensis, infections are normally less severe (Brock et al., 1983; Lightner et al. 1983; Bell and Lightner, 1987; Brock and lightner, 1990; Lightner, 1992).

This study was carried out in order to evaluate the presence of IlIHNV in adult blue shrimp, $P$. stylirostris, in Guaymas Bay, Sonora, Mexico. This region is used to catch parent stocks of this species for aquaculture. Another objective of the
En la actualidad existe información de alrededor de una docena de enfermedades virales en camarones peneidos, tanto de origen silvestre como cultivado. En América, cuatro de estos virus (BP, IHHN, HPV y TSV) han tenido impactos importantes en las granjas y laboratorios de camarón (Brock et al., 1983). Otros virus, tales como REO III y LOVV. que afectan a los camarones están siendo caracterizados.

La presencia de IHHNV se ha detectado desde 1989 en camarones silvestres y cultivados en México, Centro y Sudamérica. Esto indica que se distribuye ampliamente en poblaciones silvestres del Pacífico americano (Lotz et al., 1989; Lightner y Redman, 1991). Los camarones cultivados y silvestres del Golfo de California para antes de 1987 se reportaban libres de IHHNV (Lightner et al., 1992). Posteriormente se hicieron algunos informes de infecciones en granjas y laboratorios. Alrededor de 1989, se realizaron algunos estudios que sugirieron que este virus parecía estar presente en poblaciones silvestres (Lotz et al., 1991). Este virus se ha detectado no solamente para las especies que comúnmente se cultivan en las Américas. como son el camarón azul (Penaeus stylirostris) y el blanco $(P$. vannamei), sino también para el camarón café ( $P$. californiensis) en el Golfo de California (PantojaMorales y Lightner, 1991). En la actualidad, el camarón café no es cultivado comercialmente, pero a futuro se considera con potencialidad para este fin en México (Magallón-Barajas et al. 1994).

El virus IHIIIN es un miembro de la familia Parvoviridae (Bonami et al., 1990). Su diámetro oscila entre 20 y $22 \mathrm{~nm}$; presenta una simetría icosahédrica. Está constituido por una cadena simple de ADN con cuatro cadenas de polipéptidos, cuyos pesos moleculares son $74,47,39$ y $37.5 \mathrm{Kd}$ (Poulos y Lightner, 1992).

El camarón azul, P. stylirostris, es sumamente susceptible a la infección por IHHNV, y algunas epizootias han ocurrido en granjas con sistemas de cultivos semiintensivos e intensivos (Lightner y Redman, 1992). En otros camarones peneidos, como $P$. semisulcatus, $P$. chinensis y $P$. 
study was to compare the percentage of infected individuals by sex and size.

\section{MATERIAL AND METHODS}

One hundred juvenile and adult blue shrimp, P. stylirostris, were caught from 23 to 29 February, 1996, in Guaymas Bay, Sonora, in northwestern Mexico, by means of a trawl net. They were taken to the ITESM laboratory in Guaymas. Biometric parameters, such as total size, cephalothorax size and weight of each individual, were recorded. The shrimp were maintained in four $10-\mathrm{m}^{3}$ fiberglass acclimation tanks, using a semi-closed system with a recirculation of $400 \%$ and a water exchange of $50 \%$ per day. Temperature was increased from 23 to $26^{\circ} \mathrm{C}$ and salinity maintained at $35 \mathrm{ppt}$. The shrimp were fed fresh squid, fresh clam and a formulated shrimp diet, Rangen $35 \% \operatorname{Pr}(70 \%, 25 \%$ and $5 \%$ of the feeding rate, respectively). The feeding rate was $15 \%$ of shrimp biomass. The shrimp were observed during the acclimation period in order to detcct signs of possible infection. After one week of acclimation, the shrimp were individually evaluated under laboratory conditions for the presence of IHHNV, using the non-lethal method known as hybridization by immobilization (Dot Blot, DiagXotics, Inc.).

\section{RESULTS AND DISCUSSION}

Table 1 shows the total number of shrimp analyzed and infected with the IHHN virus, as well as numbers and percentages by sex; 49 of the shrimp studied were infected with the IHHN virus. This represents almost half of the total analyzed and indicates the extent of the problem. The IHHN virus was present in 27 of the 50 males studied, representing a $54 \%$ prevalence. Of the 50 females analyzed, 22 were infected with the virus, representing a $44 \%$ prevalence. The percentages of infected individuals were extremely high for both sexes and the differences were not considered significant. The possibility of californiensis, las infecciones son normalmente menos severas (Brock et al., 1983; Lightner et al., 1983; Bell y Lightner, 1987; Brock y Lightner, 1990; Lightner, 1992).

Este estudio se efectuó con el fin de evaluar la presencia de IHHNV en adultos silvestres de camarón azul, $P$. stylirostris, en la Bahía de Guaymas, Sonora, México, zona de captura de reproductores. Otro objetivo del estudio fue la comparación porcentual de camarones infectados de acuerdo con el sexo y tamaño.

\section{MATERIAL Y MÉTODOS}

Se capturó un lote de 100 camarones juveniles y adultos de $P$. stylirostris, en el periodo comprendido del 23 al 29 de febrero de 1996, en la Bahía de Guaymas, Sonora, región del noroeste de México, por medio de una red de arrastre. Los camarones fueron transportados al laboratorio del ITESM en Guaymas. Se tomaron los datos biométricos correspondientes a la longitud total, longitud del cefalotórax y peso de cada camarón. Los organismos se mantuvieron en cuatro tanques de aclimatación de fibra de vidrio de $10 \mathrm{~m}^{3}$, usando un sistema semicerrado con recirculación de $400 \%$ y un recambio de agua de $50 \%$ por día. La temperatura varió de 23 a $26^{\circ} \mathrm{C}$ y la salinidad se mantuvo en $35 \mathrm{ppm}$. La alimentación fue con base de calamar fresco, almeja fresca y una dieta formulada para camarón marca Rangen con 35\% de proteína $(70 \%, 25 \%$ y $5 \%$ de la racíon diaria, respectivamente). Se alimentó diariamente a razón del $15 \%$ de la biomasa de camarón en cada tanque. Durante la aclimatación, los camarones fueron observados con el fin de detectar características o señales que indicaran alguna posible enfermedad. Después de una semana de aclimatación de los organismos a las condiciones de laboratorio, y que la biopsia no letal del corte de endo y exopodito del cuarto par de pleópodos no provoque mortalidad, se realizó la hibridación por inmovilización (Dot Blot DiagXotics, Inc.) en los camarones. 
Table 1. Number and prevalence of shrimp analyzed and infected with IHHNV in (juaymas Bay, Sonora, Mexico (total and by sex).

Tabla 1. Número y prevalencia de organismos analizados e infectados con IHHNV de la Bahía de Guaymas. Sonora, México (total y por sexo).

\begin{tabular}{lccc}
\hline & Shrimp analyzed & Shrimp infected & Prevalence $(\%)$ \\
\hline Total & 100 & 49 & 49 \\
Males & 50 & 27 & 54 \\
Females & 50 & 22 & 44 \\
\hline
\end{tabular}

acquiring parent stocks without infected individuals is practically nonexistent.

Table 2 presents the results of the analysis of the five different size classes of both sexes. The male size classes $36-40,46-50$ and $31-35 \mathrm{~mm}$ of cephalothorax were more often infected than the remaining two size classes. In females; infections were more frequent in size classes 36-40, 31-35 and $41-45 \mathrm{~mm}$ of cephalothorax. In both sexes, the biggest sizes (51-55 mm of cephalothorax) were not affected by the virus. In the smallest sizes ( $31-35 \mathrm{~mm}$ of cephalothorax). IHHNV was present in half of the shrimp. However, only four individuals of this size were analyzed and the results are probably not statistically valid. Some studies suggest that the immunological responses of shrimp are dependent on size and age (Amirante. 1986). It is probable that the immunological systems could be more developed in shrimp with sizes over 41-50 $\mathrm{mm}$ of cephalothorax.

It is important to note that the shrimp studied showed a normal appearance. None of the signs of disease produced by the IHHN virus, such as abnormal swimming, a whitish or brown shell, opaque abdominal muscle, low resistance to stress, abnormal molting, lethargy or anorexia (Lightner et al, 1983), were observed in them. Another manifestation of the viral infection is a large distribution of sizes (Kalagayan et al, 1991), but it was not observed in this case. Lightner et al. (1983) and Bell and Lightner (1984) report that the IHHN virus could be

\section{RESULTADOS Y DISCUSIÓN}

La tabla 1 muestra el total de camarones analizados, así como también el número y porcentaje por sexo de camarones infectados con el virus IHHN; 49 camarones, del total analizado, presentaron el virus. Esto representa casi la mitad del total analizado e indica el alcance del problema. En 27 de los 50 camarones machos estudiados se presentó el virus IHHN, lo que representa un $54 \%$. Para el caso de los 50 camarones hembras analizados, 22 se encontraron infectados con el virus; esto representa un $44 \%$. Los porcentajes de individuos infectados fueron sumamente altos para ambos sexos y no existieron diferencias significativas. La posibilidad de la existencia de reproductores silvestres libres de esta infección es prácticamente nula.

La tabla 2 presenta los resultados del análisis de cinco diferentes clases de tallas en ambos sexos. Los machos que se clasificaron como de 31-35, 36-40 y 46-50 mm de cefalotórax son los que presentaron la infección más frecuentemente que las otras dos tallas. En hembras, las infecciones se presentaron más en los tamaños de 31-35, 36-40 y 41-45 $\mathrm{mm}$ de cefalotórax. En ambos sexos, las tallas más grandes $(51-55 \mathrm{~mm}$ de cefalotórax) no fueron afectados por el virus. En las tallas más pequenas (31-35 $\mathrm{mm}$ de cefalotórax), el virus IHHN estuvo presente en la mitad de los camarones. Sin embargo, únicamente cuatro individuos de este tamaño se analizaron, por lo que los resultados no son estadísticamente válidos. 
Table 2. Number and percentage of shrimp analyzed and infected with IHHNV, by sex and size (in millimcters of cephalothorax), in Guaymas Bay, Sonora, Mexico.

Tabla 2. Número y prevalencia de camarones analizados e infectados con IHHNV, por sexo y talla (en milimetros de eefalotórax), de la Bahía de Guaymas, Sonora, México.

\begin{tabular}{|c|c|c|c|}
\hline & Shrimp analyzed & Shrimp infected & Prevalence $(\%)$ \\
\hline \multicolumn{4}{|l|}{ Males } \\
\hline $31-35 \mathrm{~mm}$ & 2 & 1 & 50.0 \\
\hline $36-40 \mathrm{~mm}$ & 22 & 15 & 68.1 \\
\hline $41-45 \mathrm{~mm}$ & 24 & 6 & 25.0 \\
\hline $46-50 \mathrm{~mm}$ & 2 & 1 & 0.0 \\
\hline $51-55 \mathrm{~mm}$ & 0 & 0 & 0.0 \\
\hline \multicolumn{4}{|l|}{ Females } \\
\hline $31-35 \mathrm{~mm}$ & 2 & 1 & 50.0 \\
\hline $36-40 \mathrm{~mm}$ & 7 & 4 & 57.1 \\
\hline $41-45 \mathrm{~mm}$ & 15 & 7 & 46.7 \\
\hline $46-50 \mathrm{~mm}$ & 23 & 5 & 21.7 \\
\hline $51-55 \mathrm{~mm}$ & 3 & 0 & 0.0 \\
\hline \multicolumn{4}{|c|}{ Males + females } \\
\hline $31-35 \mathrm{~mm}$ & 4 & 2 & 50.0 \\
\hline $36-40 \mathrm{~mm}$ & 31 & 21 & 67.7 \\
\hline $41-45 \mathrm{~mm}$ & 37 & 11 & 29.7 \\
\hline $46-50 \mathrm{~mm}$ & 25 & 6 & 24.0 \\
\hline $51-55 \mathrm{~mm}$ & 3 & 0 & 0.0 \\
\hline
\end{tabular}

present in asymptomatic individuals of $P$. stylirostris.

At present there is not enough information to confirm that the IHHN virus is now enzootic, which implies a balanced coexistence between pathogen and host (Fuxa and Tanada, 1987). More samplings and evaluations in this region are needed to support that statement.

\section{ACKOWLEDGEMENTS}

Thanks to ITESM, Guaymas Campus, for providing the facilities during this study.
Algunos estudios sugieren que las respuestas inmunológicas del camarón son dependientes del tamaño y la edad (Amirante, 1986). Es probable que el sistema inmunológico del camarón se desarrolle más en tamaños de 41-50 $\mathrm{mm}$ de cefalotórax.

Es importante mencionar que los camarones estudiados presentaron un aspecto normal. Ninguna de las características producidas por la enfermedad del virus IHHN fueron detectadas, tal como: nado anormal, exoesqueleto blanquecino o marrón, baja resistencia al estrés, músculo abdominal opaco, muda anormal, letargia y anorexia 


\section{REFERENCES}

Amirante, G.A. (1986). Cellular immune responses in crustaceans. In: A.P. Gupta (ed.), Hemocytic and Humaral Immunity in Arthropods. John Wiley, New York, pp. 62-75.

Bell, T.A. and Lightner, D.V. (1984). IHHN virus: infectivity and pathogenicity studies in Penaeus stylirostris and Penaeus vannamei. Aquaculture, 38: 185-194.

Bell, T.A. and Lightner, D.V. (1987). IHHN disease of Penaeus stylirostris: effects of shrimp size on disease expression. J. Fish Dis., 10: 165-170.

Bonami, J.R., Brehelin, M., Mari, J., Trumper, B. and Lightner, D.V. (1990). Purification and characterization of IHHN virus of penaeid shrimp. J. Gen. Virol., 71 : 2657-2664.

Brock, J.A. and Lightner, D.V. (1990). Diseases of Crustacea. Diseases caused by microorganisms. In: O. Kinne (ed.), Diseases of Marine Animals. Vol. 3. John Wiley, New York, pp. 245-349.

Brock, J.A., Lightner, D.V. and Bell, T.A. (1983). A review of four viruses (BP, MBV, BMN and IIIIN). Diseases of penaeid shrimp with particular reference of clinical significance, diagnosis and control in shrimp aquaculture. Proc. 71st Inti. Council for the Exploration of the Sea, C.M. 1983/Gen: 10/1-18.

Conroy, D.A. and Conroy, G. (1990). Manual de Patología de los Camarones Peneidos. 2da ed. Univ. de Venezuela, pp. 1-6.

Fuxa, J.R. and Tanada, Y. (1987). Epidemiological concepts applied to insect epizootiology. In: J.R. Fuxa and Y. Tanada (eds.), Fpizootiology of Insect Diseases. Wiley Interscience, pp. 4-2l .

Kalagayan, H., Godin, D., Kanna, R., Hagino, G., Sweeney, J., Wyban, J. and Brock, J. (1991). IHHN virus as an etiological factor in runtdeformity syndrome (RDS) of juvenile Penaeus vannamei cultured in Hawaii. J. World Aquacul. Soc., 22(4): 235-243.

Lightner, D.V. (1992). Shrimp virus diseases: Diagnosis, distribution and management. In: J. Wyban (ed.), Proc. Special Session on Shrimp Farming World Aquaculture Soc., Baton Rouge, pp. 238-253.

Lightner, D.V. and Redman, R.M (1991) Hosts, geographic range and diagnostic procedures for the penaeid viruses of concern to shrimp culturists in the Americas. In: P. De Loach. W I. Doıgherty
(Lightner et al., 1983). Otra manifestación de la infección viral es una distribución amplia de tallas (Kalagayan et al., 1991), que no se observó en este caso. Lightner et al. (1983) y Bell y Lightner (1984) mencionan que el virus IIIIIN podría estar presente en individuos de $P$. stylirostris $\sin$ presentar la sintomatología característica de la enfermedad.

En la actualidad no hay información suficiente para confirmar que el virus IHHN es enzoótico, lo cual implica una coexistencia equilibrada entre el patógeno y hospedante (Fuxa y Tanada, 1987). Son necesarios más muestreos y evaluaciones en esta región para apoyar esta afirmación.

\section{AGRADECIMIENTOS}

Se agradece al ITESM, Campus Guaymas, el haber permitido el uso de sus instalaciones para la realización del estudio.

Traducido al español por los autores.

and M.A. Davidson (eds.), Frontiers of Shrimp Research. Elsevier, pp. 173-196.

Lightner, D.V. and Redman, R.M. (1992). Penaeid virus diseases of the shrimp culture industry of the Americas. Chapter 26. In: A.W. Fast and L.J. Lesters (eds.), Marine Shrimp Culture: Principles and Practices. Elsevier, pp. 569-588.

Lightner, D.V., Redman, R.M., Bell, T.A. and Brock, J.A. (1983). Detection of IHHN virus in Penaeus stylirostris and $P$. vannamei imported into Hawaii from South and Central America. In: T.A. Bell and D.V. Lightner (1984), IHHN virus: infectivity and pathogenicity studies in Penaeus stylirostris and Penatus vannamei. Aquaculture, 38: 185-194

Lightner, D.V., Williams, R.R., Bell, T.A., Redman R.M. and Perez, L.A. (1992). A collection of case histories documenting the introduction and spread of the virus disease IHHN in penaeid shrimp culture facilities in northwestern Mexico. ICES Mar. Sci. Symp, 194: 97-105.

Lotz, J.M., Overstreet, R.M., Lightner, D.V. and Redman, R.M. (1989). Occurrence of IHHN virus in penaeid shrimp from wild populations of the 
eastern Pacific Ocean. World Aquaculture Soc., 22nd Annual Conf. and Expo. Program and Abstracts, 40.

Magallón-Barajas, F., Porchas-Cornejo, M., CamposRamos, R. and Portillo-Clarck, G. (1994). Penaeus californiensis as a cold tolerant species in Baja California Sur. Mexico. Abstracts, World Aquaculture Soc. Meeting: Aquaculture 94', New Orleans, No. 1184.

Pantoja-Morales. C. and Lightner, D.V. (1991). Status of the presence of IHHN virus in wild penaeid shrimp from the coast of Sonora, Mexico. Soc.
Invertebrate Pathology. Program and Abstracts, XXIV Annual Meeting, Northern Arizona Univ., p. 39.

Poulos, B.T. and Lightner, D.V. (1992). Recent developments in penaeid virology: Biotechnology applications for disease diagnosis of shrimp viruses of concern in Mexico and the Americas. En: Ma. C. Báez, J.A. López y L.A. Pérez-Provenzano, Jr., (eds.), Reunión sobre Nutrición y Biopatologia Acuicola. Academic Press, p. 2

Rosenberry, B. (1995). Shrimp World Production, 1995. In: Shrimp News International. San Diego, USA. 